\title{
Gazdynamic characteristics of the centrifugal compressor calculation
}

\author{
M. Kalinkevych, V. Ihnatenko \\ Sumy State University, 2 Rymskogo-Korsakova St., Sumy, 40007, Ukraine
}

\begin{abstract}
Gas-dynamic characteristics of the compressor make it possible to evaluate its energy and economic properties, to predict the values of capacity, the generated gas pressure and the power consumption during the compressor operation. For more in-depth consideration of the compressor, it is desirable to have the characteristics of its individual stages. The element-by-element analysis of the characteristics of each stage makes it possible to improve the coordination of the operation of the individual elements with each other and thereby improve the gas-dynamic characteristics of the compressor. The loss factor $\zeta$ and the static pressure recovery factor $\xi$ can be used as the values characterizing the properties of the individual elements of the stage. Coefficients $\zeta$ and $\xi$ are suitable for evaluating the energy properties of any element of the stage. To assess the effect of the element in question on the economy of the stage, it is necessary to establish what proportion of the work required for compression is the "loss" of energy in a given element, i.e. find the reduction in efficiency stage $\Delta \eta$ due to dissipation of energy into heat in this element. Calculation of performance of the centrifugal compressor is performed from the inlet to the outlet using the equations of state, of process, of continuity and conservation of energy. The initial data are geometric parameters of the compressor, the composition and the initial parameters of compressed gas, the rotational speed of the rotor. The basis of the elementwise calculation of gas-dynamic characteristics is the gas-dynamic characteristics of the stage elements. The calculation can be performed using the characteristics of the stage elements taken from the own bank of experimental data or using the generalized characteristics of the stage elements. To obtain generalized characteristics of the impeller, blade and no-blade diffusers, reverse guide vanes, experimental data were used, published in the works of Galerkin, Den, Rees, Seleznev and others, as well as experimental data obtained by the author. The generalized characteristics are obtained in the form of analytical dependences of the loss coefficients on the angles of attack or flow angles by approximation of experimental data. These dependences were used to analyze the gas-dynamic characteristics of a centrifugal compressor, which made it possible to develop recommendations for their improvement.
\end{abstract}

Keywords: Centrifugal Compressor, Stage, Elementwise Analysis, Performance, Impeller, Diffuser

(C) The Author(s) 2018. This article is an open access publication

This work is licensed under the Creative Commons Attribution 4.0 International License (CC BY) http://creativecommons.org/licenses/by/4.0/

\section{Introduction}

Gasdynamic characteristics of the compressor make it possible to evaluate its energy and economic properties, to predict the values of capacity, the generated gas pressure, the power consumption during the compressor operation. For more in-depth consideration of the compressor, it is desirable to have the characteristics of its individual stages. The element-by-element analysis of the characteristics of each stage makes it possible to improve the coordination of the operation of the individual elements with each other and thereby improve the gas-dynamic characteristics of the compressor.

The values characterizing the properties of the individual elements of the stage can be the loss factor and the static pressure recovery factor. Coefficients and are suitable for evaluating the energy properties of any element of the stage. To assess the effect of the element in question on the economy of the stage, it is necessary to establish what proportion of the work required for compression is the "loss" of energy in a given element, i.e. find the reduction in efficiency stage due to dissipation of energy into heat in the element under consideration. The elementwise analysis of the compressor's work can be a powerful tool for improving its flowing part. The creation of software for elementwise calculation of gasdynamic characteristics of a centrifugal compressor is undoubtedly an actuation one.

\section{Gasdynamic characteristics calculation method}

Calculation of the gasdynamic characteristics of the compressor is carried out in series from the inlet to the outlet, using the equations of state, process, continuity and conservation of energy $[1,2]$.

The initial data are the geometric parameters of the compressor, the composition and initial parameters of the compressible gas, the rotor speed. The number of calculated compressor operating conditions by flow rate is usually not more than 10 .

Initial calculation data. The initial data are:

1) geometric parameters (Fig. 1): $\mathrm{d} 0$ - small diameter at the impeller inlet; D0 - large diameter at the impeller inlet; D1 - diameter at the impeller blade inlet; D2 - diameter at the impeller blade outlet;

D3 - diameter at the diffuser inlet;

D4 - diameter at the diffuser outlet; 
D5 - diameter at the return channel inlet;

b1 - width at the impeller blade inlet;

b2 - width at the impeller blade outlet;

b3 - width at the diffuser inlet;

b4 - width at the diffuser outlet;

b5 - width at the return channel inlet;

$\beta_{b 1}$ - angle at the impeller blade inlet;

$\beta_{b 2}$ - angle at the impeller blade outlet;

$\alpha_{b 3}$ - angle at the diffuser inlet;

$\alpha_{b 4}$ - angle at the diffuser outlet;

$\alpha_{b 5}$ - angle at the return channel inlet;

$\alpha_{b 6}$ - angle at the return channel outlet;

$z_{1}, z_{3}, z_{5}$ - quantity of blades of impeller,

diffuser and return channel respectively.

2) gas parameters:

$R$ - gas constant, $\mathrm{J} /(\mathrm{kg} \mathrm{K})$;

$k$ - adiabatic index;

$c_{p}$ - isobaric specific heat, $\mathrm{J} /(\mathrm{kg} \mathrm{K})$;

$z$ - coefficient of compressibility;

$p_{\text {in }}, T_{\text {in }}$ - pressure and temperature of gas at the compressor inlet;

3) gasdynamic characteristics of the elements stage:

$\zeta_{i m p}=f_{1}\left(i_{1}\right)$, where $\zeta_{i m p}-$ loss factor of the impeller; $i_{1}-$ angle of attack at the impeller blade inlet;

$\zeta_{\text {dif } 2-3}=f_{2}\left(\alpha_{2}\right)$, where $\zeta_{\text {dif 2-3 }}-$ loss factor of the

vaneless diffuser (initial section);

$\alpha_{2}$ - angle of the flow at the impeller outlet;

$\zeta_{\text {dif 3-4 }}=f_{3}\left(\alpha_{3}\right)$, where $\zeta_{\text {dif 3-4 }}-$ loss factor of the

vaneless diffuser (main section); $\alpha_{3}$ - angle of the

flow at the diffuser inlet;

$\zeta_{v \text {.dif }}=f_{4}\left(i_{3}\right)$, where $\zeta_{v \text {.dif }}-$ loss factor of the vane diffuser; $i_{3}$ - angle of attack at the diffuser blade inlet;

$\zeta_{c . d i f}=f_{5}\left(i_{3}\right)$, where $\zeta_{c . d i f}-$ loss factor of the channel diffuser; $i_{3}$ - angle of attack at the channel diffuser inlet;

$\zeta_{R C}=f_{6}\left(i_{5}\right)$, where $\zeta_{R C}-$ loss factor of the return channel; $i_{5}$ - angle of attack at the return channel inlet;

$\zeta_{\text {vol }}=f_{7}\left(\alpha_{4}\right)$, where $\zeta_{v o l}-$ loss factor of the volute; $\alpha_{4}-$ angle of the flow at the diffuser outlet.

\section{Algorithm of calculation}

1. Volume flow rate of gas at the compressor inlet

$$
\bar{V}_{i n}=\left[a+\frac{b-a}{N_{1}-1} \cdot(i-1)\right] \cdot \bar{V}_{i n . n} .
$$

$\bar{V}_{\text {in }}$ - volume flow at specified operating condition; $\bar{V}_{i n . n}$ - volume flow at nominal operating condition; $N_{1}-$ operating conditions quantity; $i$ - operating condition number; $a$ and $b$ - coefficients for minimum and maximum flow rate (for example $a=0,5 ; b=1,5$ ).
2. Gas velocity at the stage inlet $c_{i n}=\frac{\bar{V}_{i n}}{A_{i n}}$, where $A_{i n}-$ area stage at the inlet.

3. Gas density at the compressor inlet

$$
\rho_{\text {in }}=\frac{p_{\text {in }}}{z_{\text {in }} \cdot R \cdot T_{\text {in }}} .
$$

4. Mass flow of gas $\bar{m}=\bar{V}_{i n} \cdot \rho_{i n}$.

5. Total pressure loss in the input device

$$
\Delta p_{i n-o}^{*}=\zeta_{i n} \cdot \rho_{i n} \frac{c_{i n}^{2}}{2} .
$$

6. Total pressure at the impeller inlet

$$
p_{0}^{*}=p_{i n}+\rho_{i n} \frac{c_{i n}^{2}}{2}-\Delta \partial_{i n-\hat{\imath}}^{*} .
$$

7. Total temperature at the impeller inlet

$$
T_{0}^{*}=T_{i n}+\frac{\tilde{N}_{i n}^{2}}{2 \cdot c_{\delta}} .
$$

8. Total density at the impeller inlet

$$
\rho_{0}^{*}=\frac{p_{0}^{*}}{z \cdot R \cdot T_{0}^{*}} .
$$

9. Static density at the impeller inlet

$$
\rho_{0}=0,5 \cdot\left[\rho_{0}^{*}+\left(\rho_{0}^{* 2}-\frac{2 \cdot a_{0}^{2}}{k \cdot R \cdot T_{0}^{*}}\right)^{0,5}\right],
$$

where $a_{0}=4 \cdot \bar{m} / \pi \cdot\left(D_{0}^{2}-d_{0}^{2}\right) \cdot \sin \alpha_{1} ; \alpha_{1}-$ flow angle in absolute motion at the impeller inlet.

10. Absolute velocity at the impeller inlet

$$
c_{0}=a_{0} / \rho_{0} \text {. }
$$

11. Volume flow rate of gas at the impeller inlet

$$
\bar{V}_{0}=\bar{m} / \rho_{0} \text {. }
$$

12. Static temperature at the impeller inlet

$$
T_{0}=T_{0}^{*}-c_{0}^{2} / 2 \cdot c_{p} .
$$

13. Radial velocity at the impeller inlet

$$
c_{r 1}=\bar{V}_{0} / \pi \cdot D_{1} \cdot b_{1} \text {. }
$$

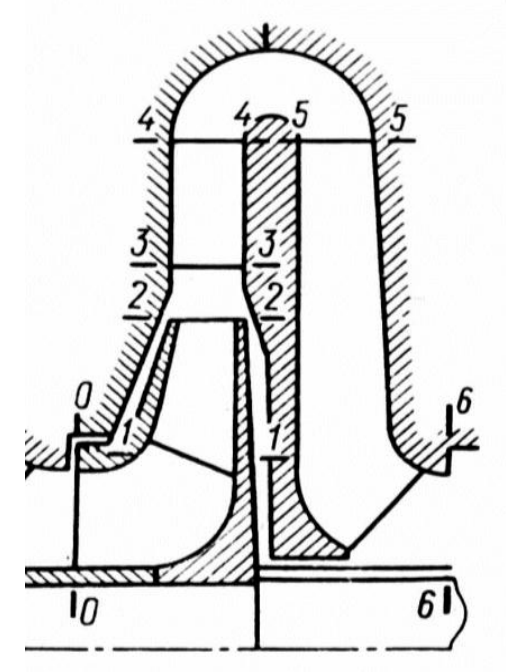

Figure 1- Scheme of centrifugal compressor 
14. Circumferential velocity on the diameter $D_{1}$

$$
U_{1}=\left(\omega \cdot D_{1}\right) / 2 \text {. }
$$

15. Relative flow angle $\beta_{1}=\operatorname{arctg}\left(\frac{c_{r 1}}{U_{1}-c_{u 1}}\right)$.

16. Angle of attack at the impeller blade inlet

$$
i_{1}=\beta_{b 1}-\beta_{1} \text {. }
$$

17. Relative flow velocity $w_{1}=c_{r 1} / \sin \beta_{1}$.

18. Loss factor of the impeller $\zeta_{\text {imp }}=f_{1}\left(i_{1}\right)$.

19. Radial velocity at the impeller outlet

$$
c_{r 2}=\frac{\bar{V}_{0}}{\varepsilon_{2} \cdot \pi \cdot D_{2} \cdot b_{2}}, \text { where } \varepsilon_{2}=\rho_{2} / \rho_{0} .
$$

20. Coefficient of flow $\varphi_{r 2}=c_{r 2} / U_{2}$.

21. Coefficient of theoretical head

$$
\psi_{t h}=\psi_{t h 2}-\left(c_{u 1} \cdot U_{1}\right) / U_{2}^{2},
$$

where $\psi_{t h 2}=1-\varphi_{r 2} \cdot \operatorname{ctg} \beta_{b 2}-\frac{\pi}{z_{2}} \cdot \sin \beta_{b 2}-$ the equation

Stodola.

22. Coefficient of total head

$$
\psi_{t}=\psi_{t h}\left(1+\beta_{f r}+\beta_{\text {over }}\right) .
$$

23. Absolute velocity at the impeller outlet

$$
c_{2}=U_{2} \cdot \sqrt{{\varphi_{r 2}{ }^{2}+\psi_{t h 2}{ }^{2}}^{2}} .
$$

24. Reactivity $\Omega=1-\frac{c_{2}^{2}-c_{0}^{2}}{2 \cdot \psi_{t} \cdot U_{2}^{2}}$.

25. Total temperature at the impeller outlet

$$
T_{2}^{*}=T_{0}^{*}+\frac{\psi_{i} \cdot U_{2}^{2}}{c_{p}} .
$$

26. Static temperature at the impeller outlet

$$
T_{2}=T_{2}^{*}-\frac{c_{2}^{2}}{2 \cdot c_{p}} .
$$

27. Density ratio $\varepsilon_{2}^{\prime}=\left(\frac{T_{2}}{T_{0}}\right)^{(\sigma-1)}$

where $\sigma=\frac{n}{n-1}=\frac{k}{k-1}\left(1-\zeta_{0-2} \frac{w_{1}^{2}}{U_{2}^{2} \cdot 2 \cdot \Omega_{i} \cdot \psi_{i}}\right)$.

28. Static density at the impeller outlet

$$
\rho_{2}=\varepsilon_{2}^{\prime} \cdot \rho_{0} \text {. }
$$

29. Static pressure at the impeller outlet

$$
p_{2}=\rho_{2} \cdot R \cdot T_{2} \cdot z \text {. }
$$

30. Total pressure at the impeller outlet

$$
p_{2}^{*}=p_{2}+\rho_{2} \cdot \frac{c_{2}^{2}}{2} \text {. }
$$

31. Total head $h_{t}=\psi_{t} \cdot U_{2}^{2}$.

32. Loss coefficient efficiency of the impeller

$$
\Delta \eta_{\text {imp }}=\zeta_{\text {imp }} \cdot \frac{w_{1}^{2}}{2 \cdot h_{t}} .
$$

33. Flow angle at the impeller outlet

$$
\alpha_{2}=\operatorname{arctrg}\left(\varphi_{r 2} / \psi_{t h 2}\right) \text {. }
$$

34. Loss factor of the vaneless diffuser (initial section) $\zeta_{2-3}=f_{2}\left(\alpha_{2}\right)$.
35. Loss coefficient efficiency of the diffuser (initial section) $\Delta \eta_{2-3}=\zeta_{2-3} \cdot \frac{c_{2}^{2}}{2 \cdot h_{t}}$.

36. Total pressure at the cross-section $3-3$

$$
P_{3}^{*}=P_{2}^{*}-\zeta_{2-3} \cdot \frac{c_{2}^{2}}{2} \cdot \rho_{2} \text {. }
$$

37. Flow angle at the cross-section 3-3

$$
\alpha_{3}=\operatorname{arctg}\left(\frac{b_{2}}{b_{3}} \cdot \operatorname{tg} \alpha_{2}\right) \text {. }
$$

38. Total density at the cross-section 3-3

$$
\rho_{3}^{*}=\frac{p_{3}^{*}}{z \cdot R \cdot T_{3}^{*}} .
$$

39. Static density at the cross-section 3-3

$$
\rho_{3}=0,5 \cdot\left(\rho_{3}^{*}+\sqrt{\rho_{3}^{* 2}-\frac{2 a_{3}^{2}}{k \cdot R \cdot T_{3}^{*} \cdot z}}\right),
$$

where $a_{3}=\frac{\bar{m}}{\pi \cdot D_{3} \cdot b_{3} \cdot \sin \alpha_{3}}$.

40. Velocity at the cross-section 3-3 $c_{3}=a_{3} / \rho_{3}$.

Depending on the type of diffuser, the corresponding algorithm is taken.

\section{For vaneless diffuser}

41. Loss factor of the vaneless diffuser (main section) $\zeta_{\text {dif } 3-4}=f_{3}\left(\alpha_{3}\right)$.

42. Loss coefficient efficiency of the vaneless diffuser $\Delta \eta_{3-4}=\zeta_{\text {dif } 3-4} \cdot \frac{c_{3}^{2}}{2 \cdot h_{t}}$.

43. Flow angle at the diffuser outlet $\operatorname{tg} \alpha_{4}=\operatorname{tg} \alpha_{3} \cdot\left(b_{3} / b_{4}\right)$.

For vane diffuser

44. Angle of attack at the vane diffuser $i_{3}=\alpha_{b 3}-\alpha_{3}$.

45. Loss factor of the vane diffuser $\zeta_{v \text {.dif }}=f_{4}\left(i_{3}\right)$.

46. Loss coefficient efficiency of the vane diffuser

$$
\Delta \eta_{3-4}=\zeta_{v . d i f} \cdot \frac{c_{3}^{2}}{2 \cdot h_{t}} .
$$

For channel diffuser

47. Angle of attack at the channel diffuser $i_{3}=\alpha_{b 3}-\alpha_{3}$.

48. Loss factor of the channel diffuser $\zeta_{c . \text { dif }}=f_{5}\left(i_{3}\right)$.

49. Loss coefficient efficiency of the channel diffuser $\Delta \eta_{3-4}=\zeta_{c . d i f} \cdot \frac{c_{3}^{2}}{2 \cdot h_{t}}$.

For vane or channel diffusers

50. Flow angle at the diffuser outlet $\alpha_{4}=\alpha_{b 4}-\Delta \alpha_{4}$, where $\Delta \alpha_{4}-$ angle of lag.

For vaneless, vane or channel diffusers

51. Total pressure at the diffuser outlet

$$
p_{4}^{*}=p_{3}^{*}-0,5 \cdot \zeta_{3-4} \cdot \rho_{3} \cdot c_{3}^{2} .
$$

52. Total density at the diffuser outlet 


$$
\rho_{4}^{*}=\frac{p_{4}^{*}}{z \cdot R \cdot T_{4}^{*}} .
$$

53. Static density at the diffuser outlet

$$
\rho_{4}=0,5\left(\rho_{4}^{*}+\sqrt{\rho_{4}^{* 2}-\frac{2 a_{4}^{2}}{k \cdot R \cdot T_{4}^{*} \cdot z}}\right),
$$

where $a_{4}=\frac{\bar{m}}{\pi \cdot D_{4} \cdot b_{4} \cdot \sin \alpha_{4}}$.

54. Velocity at the diffuser outlet $c_{4}=a_{4} / \rho_{4}$.

55. Coefficient of friction at the return channel

$$
k_{f r}=\left(0,075 \cdot\left(\frac{b_{5}}{b_{4}}\right)^{2}-0,15 \cdot \frac{b_{5}}{b_{4}}+1,075\right)^{-1} .
$$

56. Flow angle at the return channel inlet

$$
\alpha_{5}=\operatorname{arctg}\left(\operatorname{tg} \alpha_{4} \cdot \frac{D_{4} \cdot b_{4}}{D_{5} \cdot b_{5}} \cdot k_{f r}\right) .
$$

57. Angle of attack at the return channel

$$
i_{5}=\alpha_{b 5}-\alpha_{5} \text {. }
$$

58. Loss factor of the return channel $\zeta_{R C}=f_{6}\left(i_{5}\right)$.

59. Loss coefficient efficiency of the return channel $\Delta \eta_{R C}=\zeta_{R C} \cdot \frac{c_{4}^{2}}{2 \cdot h_{t}}$.

60. Loss factor of the volute $\zeta_{v o l}=f_{7}\left(\alpha_{4}\right)$.

61. Loss coefficient efficiency of the volute

$$
\Delta \eta_{v o l}=\zeta_{v o l} \cdot \frac{c_{4}^{2}}{2 \cdot h_{t}} .
$$

62. Efficiency of the stage $\eta_{p . s t}=1-\sum_{j} \Delta \eta_{j}$.

63. Conditional coefficient of flow

$$
\Phi_{0}=\frac{4 \cdot \overline{V_{0}}}{\pi \cdot D_{2}^{2} \cdot U_{2}} .
$$

64. Coefficient of polytropic head of the stage

$$
\psi_{p . s t}=\psi_{t} \cdot \eta_{p . s t} \text {. }
$$

Calculation of gas parameters at the stage outlet

65. Total pressure at the stage outlet

$$
p_{0^{\prime}}^{*}=p_{4}^{*}-0,5 \cdot \zeta_{4-0^{\prime}} \cdot \rho_{4} \cdot c_{4}^{2} \text {. }
$$

66. Total density at the stage outlet $\rho_{0^{\prime}}^{*}=\frac{p_{0^{\prime}}^{*}}{z \cdot R \cdot T_{0^{\prime}}^{*}}$.

67. Static density at the stage outlet

$$
\rho_{0^{\prime}}=0,5\left(\rho_{0^{\prime}}^{*}+\sqrt{\rho_{0^{\prime}}^{*}-\frac{2 a_{0^{\prime}}^{2}}{k \cdot R \cdot T_{0^{\prime}}^{*}}}\right),
$$

where $a_{0^{\prime}}=\bar{m} / A_{\text {out }}$.

68. Static pressure at the stage outlet

$$
p_{0^{\prime}}=p_{0^{\prime}}^{*}-0,5 \cdot \rho_{0^{\prime}} \cdot c_{0^{\prime}}^{2} \text {. }
$$

69. Pressure ratio for stage $\ddot{I}_{s t}=p_{0^{\prime}} / p_{0}$.

70. Pressure ratio for compressor $\ddot{I}=p_{\text {out }} / p_{\text {in }}$.

71. Efficiency of the compressor

$$
\eta_{p . c}=\frac{\sum \psi_{t . s t} \cdot \eta_{p . s t}}{\sum \psi_{t . s t}} .
$$

According to the results of calculations the following graphic charts can be done $\ddot{I}=f\left(\bar{V}_{i n}\right)$ and $\eta_{p . c}=f\left(\bar{V}_{i n}\right)$ $[2,3,4]$.

\section{Obtainment of the gasdynamic characteristics of the stage elements}

The basis of the elementwise calculation of gasdynamic characteristics is the gasdynamic characteristics of the stage elements. The calculation can be performed using the characteristics of the stage elements taken from the own bank of experimental data or using the generalized characteristics of the stage elements.

For convenience of calculation automation, the experimental data $[2,3,4,5,6,7]$ were approximated using the program «UniAprox2.04» and the analytical form of the generalized characteristics was obtained.

The results of approximation for the loss factors of the stage elements are represented below.

Dependence of the loss factor on the angle of attack of the impeller are represented on figure 2.

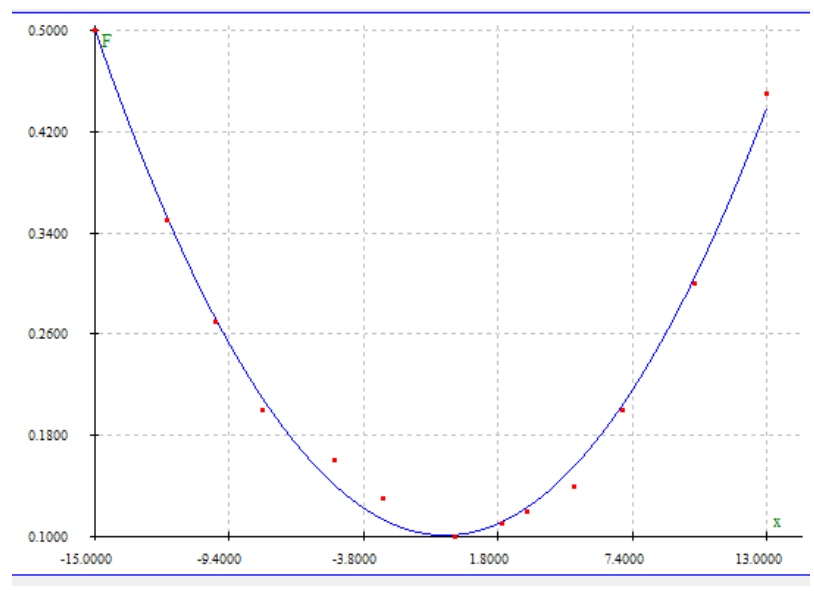

Figure 2 - Dependence of the loss factor on the angle of attack of the impeller $\zeta_{\text {imp }}=f_{1}\left(i_{1}\right)$

The equation for loss factor of the impeller $\zeta_{\text {imp }}=1,876 \cdot 10^{-3} \cdot i_{1}^{2}+1,53 \cdot 10^{-3} \cdot i_{1}+0,101$.

The angle of attack $i_{1}$ in this equation is measured in degrees. Coefficient of determination $R^{2}=99,713 \%$.

The initial segment of the vaneless diffuser is determined according to the recommendations of prof. Yu. Galerkin [2]. Dependence of the loss factor of the vaneless diffuser (initial section) on the angle of the flow at the impeller outlet are represented on figure 3.

The equation for loss factor of the vaneless diffuser (initial section)

$\zeta_{\text {dif } 2-3}=3,92 \cdot 10^{-4} \cdot \alpha_{2}{ }^{2}-2,3 \cdot 10^{-2} \cdot \alpha_{2}+0,437$.

The angle $\alpha_{2}$ in this equation is measured in degrees. Coefficient of determination $R^{2}=99,843 \%$. 


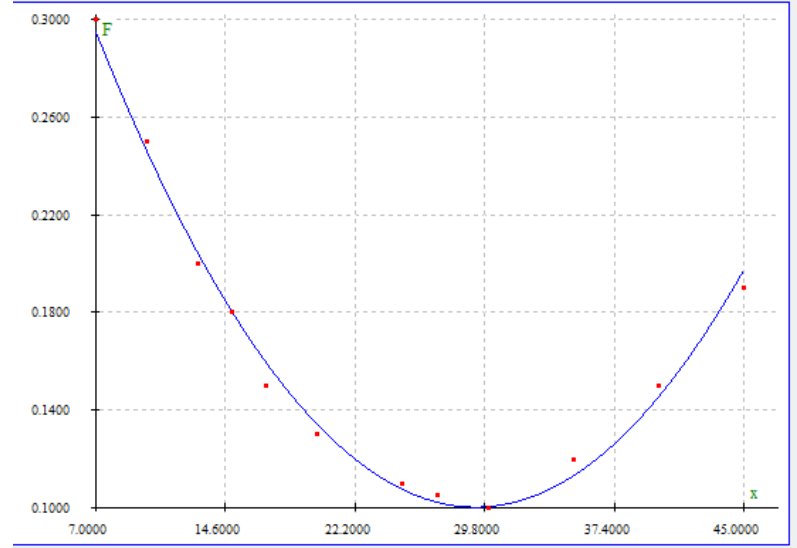

Figure 3 - Dependence of the loss factor of the vaneless diffuser (initial section \} on the angle of the flow at the impeller outlet $\zeta_{\text {dif } 2-3}=f_{2}\left(\alpha_{2}\right)$

Dependence of the loss factor of the vaneless diffuser (main section $\}$ on the angle of the flow are represented on figure 4 .

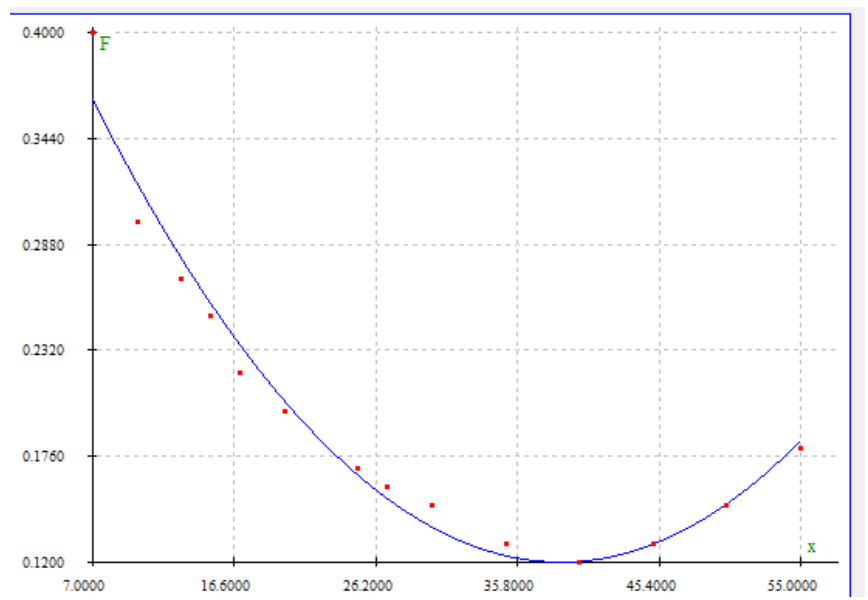

Figure 4-Dependence of the loss factor of the vaneless diffuser (main section) on the angle of the flow

$$
\zeta_{\text {dif } 3-4}=f_{3}\left(\alpha_{3}\right)
$$

The equation for loss factor of the vaneless diffuser (main section)

$$
\zeta_{\text {dif } 3-4}=4,3 \cdot 10^{-4} \cdot \alpha_{3}^{2}-1,88 \cdot 10^{-2} \cdot \alpha_{3}+0,484 \text {. }
$$

The angle $\alpha_{3}$ in this equation is measured in degrees. Coefficient of determination $R^{2}=99,628 \%$.

Dependence of the loss factor of the vane diffuser on the angle of attack are represented on figure 5 .

The equation for loss factor of the vane diffuser $\zeta_{\text {v.dif }}=1,87 \cdot 10^{-3} \cdot i_{3}^{2}+1,39 \cdot 10^{-2} \cdot i_{3}+0,238$.

The angle of attack $i_{3}$ in this equation is measured in degrees. Coefficient of determination $R^{2}=98,925 \%$.

Dependence of the loss factor of the return channel on the angle of attack are represented on figure 6.

The equation for loss factor of the return channel $\zeta_{R C}=1,19 \cdot 10^{-3} i_{5}^{2}+1,2 \cdot 10^{-2} i_{5}+0,33$.
The angle of attack $i_{5}$ in this equation is measured in degrees. Coefficient of determination $R^{2}=99,192 \%$.

Dependence of the loss factor of the volute on the angle of the flow at the diffuser outlet are represented on figure 7.

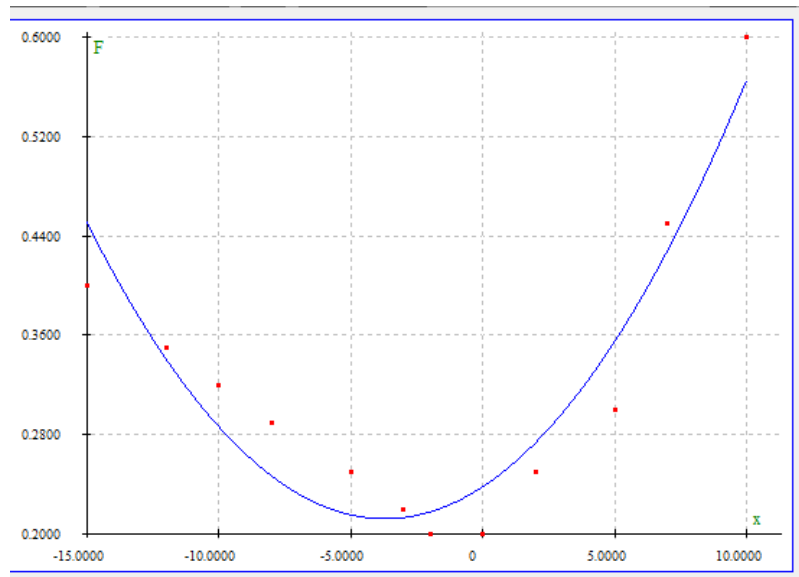

Figure 5 - Dependence of the loss factor of the vane diffuser on the angle of attack $\zeta_{v . d i f}=f_{4}\left(i_{3}\right)$

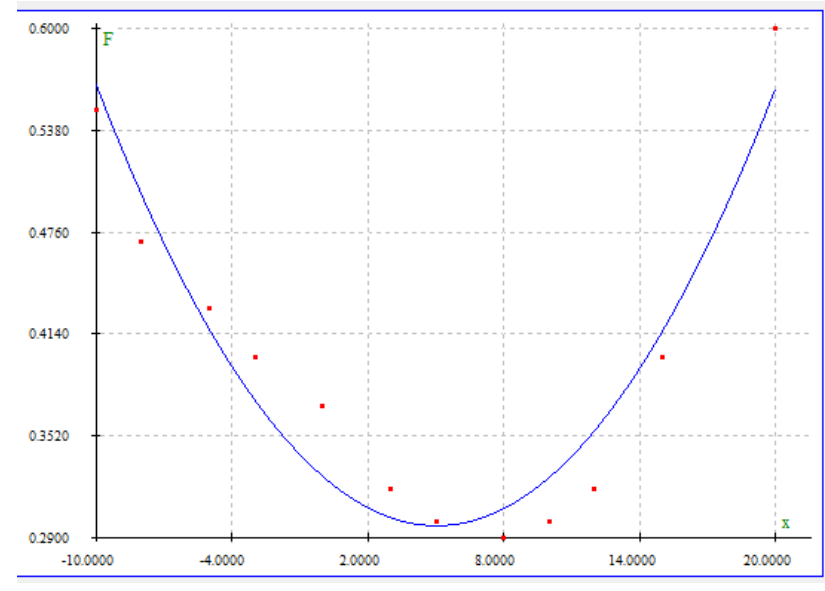

Figure 6 - Dependence of the loss factor of the return channel on the angle of attack $\zeta_{R C}=f_{6}\left(i_{5}\right)$

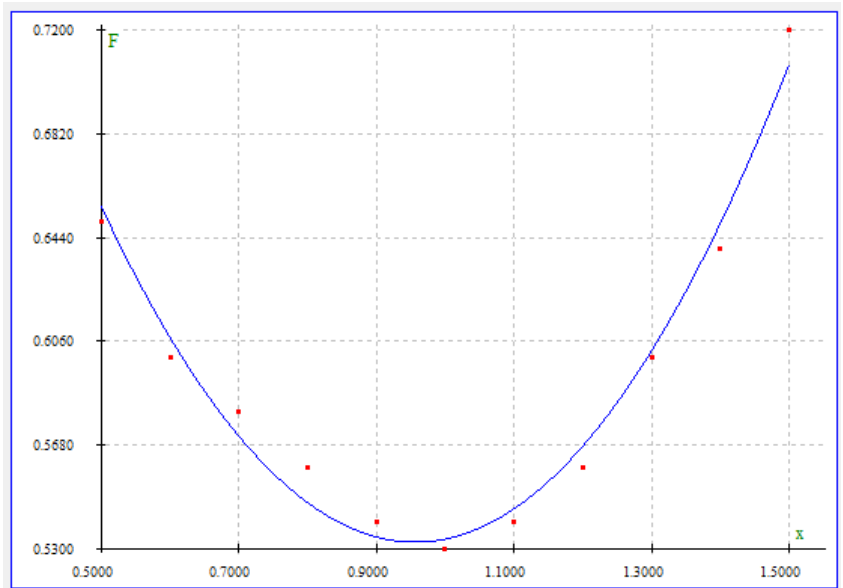

Figure 7 - Dependence of the loss factor of the volute on the angle of the flow at the diffuser outlet $\zeta_{\text {vol }}=f_{7}\left(\operatorname{tg} \alpha_{4}\right)$ 
The equation for loss factor of the volute $\zeta_{\text {vol }}=0,59\left(\operatorname{tg} \alpha_{4}\right)^{2}-1,13 \operatorname{tg} \alpha_{4}+1,024$.

In this equation $\operatorname{tg} \alpha_{4}=\operatorname{tg} \alpha_{4} / \operatorname{tg} \alpha_{4 n}$. Coefficient of determination $R^{2}=99,734 \%$.

\section{Results}

For example, an elementwise analysis of the compressor 16GTS2-340 / 60-85M is performed. The most effective operating condition is the 4 th. Figure 8 shows the data that allows you to determine how aligned the operating condition of the compressor stages are.

The loss factors of the elements of the 1st stage of the compressor are close to the minimum, but for the elements of the second stage, it is possible to reduce the values of the loss factors (increase in the efficiency). To do this, it is needed to reduce the angle of attack at the entrance to the impeller by $3-4^{0}$, increase the angle of the flow to $20^{\circ}$, reduce the angle of attack at the entrance to the vane diffuser by $4-5^{0}$. The correction of the size of the flow part, which ensures the required changes in the flow parameters, can be performed in various ways, for example by changing the width of the channels.
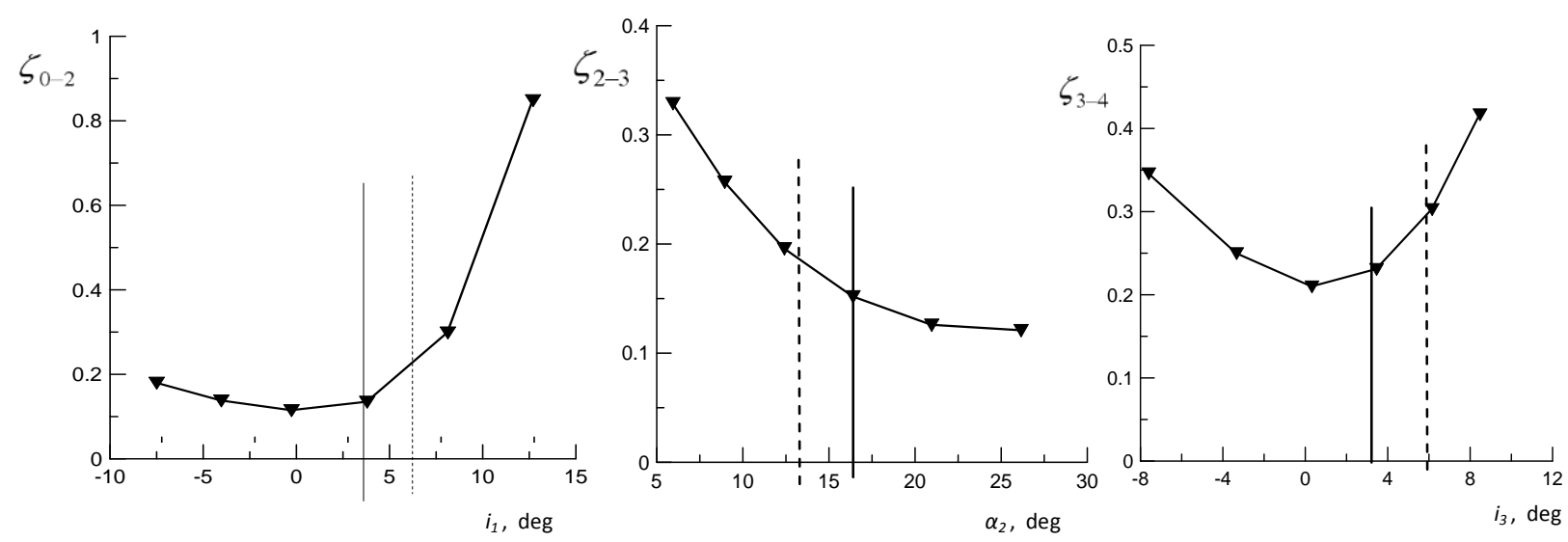

Figure 8 - The loss factors of the elements of the 1st and 2nd stages of the compressor: -1 st stage; - - - 2nd stage

\section{Conclusions}

Elementwise analysis makes it possible to improve the coordination of the work of individual elements of the stages of a centrifugal compressor with each other and, consequently, to increase its efficiency.

\section{References}

1. Dixon S. L., Hall S. A. (2010). Fluid Mechanics and Thermodynamics of Turbomachinery. Sixth edn. Elsevier Inc. $459 \mathrm{p}$.

2. Seleznev K. P., Galerkin J. B. (1982). Centrobegnie kompressory. [Centrifugal compressors (in Russian)]. Leningrad: Mashynostroyenye. $271 \mathrm{p}$.

3. Ris V.F. (1964). Centrobegnie mashiny. [Centrifugal mashine (in Russian)]. Leningrad: Mashynostroyenye. $336 \mathrm{p}$.

4. Den G. N. (1980). Proektirovanie protochnoi chasti centrobegnogo kompressora. [Design of a flowing part of a centrifugal compressor (in Russian)]. Leningrad: Mashynostroyenye. 230 p.
5. Kalinkevych M., Kalashnikov A. (2009). Research on return channels of centrifugal compressors. 6th International Conference on Compressors and their Systems. Institution of Mechanical Engineers (IMechE), City University London, UK. pp. $217-226$. ISBN -13: 978-1-84334-581-7.

6. Kalinkevych M. (1976). Issledovanie vysokonapornix stupenei s oseradialnimi kolesami dlia stacionarnix kompressorov obshego naznachenia. [Investigation of highpressure stages with axial-radial impellers for stationary general-use compressors (in Russian)]. Dissertation for the degree of Ph.D. Leningrad Polytechnic Institute. Leningrad. 7. Kalinkevych M, Obukhov O. (2011). The design of vaned diffusers of centrifugal compressors based on the given velocity distribution. 7th International Conference on Compressors and their Systems. City University London, UK. pp. 61 - 69. ISBN 978-0-85709-535-0 (e-book).

\section{Розрахунок газодінамічних характеристик відцентрового компресора}

Калінкевич Н. В., Ігнатенко В. М.

Сумський державний університет, вул. Римського-Корсакова, 2, Суми, 40007, Україна

Газодинамічні характеристики компресора дозволяють оцінювати його енергетичні та економічні властивості, передбачати значення продуктивності, тиску стискуваного газу, споживання енергії під час 
роботи компресора. Для детальнішого розгляду робочого процесу компресора бажано мати характеристики окремих елементів. Поелементний аналіз характеристик кожного ступеня дозволяє покращити узгодження роботи окремих елементів між собою та за рахунок иьього досягти покращення газодинамічних характеристик компресора. В якості характеристик елементів ступеня зазвичай використовують коефіцієнти втрат і коефіцієнти відновлення статичного тиску. Коефіцієнти придатні для оцінювання енергетичних властивостей будь-якого елемента проточної частини. Для визначення впливу елемента ступеня на економічність ступеня необхідно визначити яку частину роботи, щуо витрачається на стиснення газу, складають “втрати” енергії в даному елементі, тобто знайти величину зменшення ККД ступеня внаслідок дисипації енергї в тепло в даному елементі. Розрахунок параметрів відиентрового компресора здійснюється від входу до виходу з використанням рівнянь стану, процесу, неперервності та енергії. Вихідними даними $\epsilon$ геометричні параметри компресора, склад та початкові параметри стискуваного газу, частота обертання ротора. Основою поелементного розрахунку газодинамічних характеристик є газодинамічні характеристики елементів ступеня. Розрахунок можна виконати з використанням характеристик елементів ступеня, взятих із власного банка експериментальних даних, або з використанням узагальнених характеристик. Для отримання узагальнених характеристик робочого колеса, лопаткового та безлопаткового дифузорів, зворотного напрямного апарата використані експериментальні дані, щзо опубліковані в роботах Гальоркіна, Дена, Ріса, Селезньова та ін., а також експериментальні дані, отримані автором. Узагальнені характеристики одержані y вигляді аналітичних залежностей коефічієнтів втрат від кутів атаки або кутів потоку шляхом апроксимації експериментальних даних. Ці залежності використані під час аналізу газодинамічних характеристик відцентрового компресора, щуо дозволило розробити рекомендації з їх поліпшення.

Ключеві слова: відцентровий компресор; Ступінь; Поелементний аналіз; Продуктивність; Робоче колесо; Дифузор.

\section{Література}

1. Dixon S. L., Hall S. A. Fluid Mechanics and Thermodynamics of Turbomachinery. Sixth edn. Elsevier Inc. $-2010 .-459 \mathrm{p}$.

2. Селезнев К. П., Галеркин Ю. Б. Центробежные компрессоры. Ленинград: Машиностроение. - 1982.$271 \mathrm{c}$.

3. Рис В. Ф. Центробежные компрессоры. Ленинград: Машиностроение. - 1964. - 336 с.

4. Ден Г. Н. 1980). Проектирование проточной части центробежного компрессора. Ленинград: Машиностроение. - 1980. - 230 с.

5. Kalinkevych M., Kalashnikov A. Research on return channels of centrifugal compressors. 6th International Conference on Compressors and their Systems. Institution of Mechanical Engineers (IMechE), City University London, UK. - 2009. pp. 217 - 226. ISBN -13: 978-184334-581-7.

6. Калинкевич Н. В. Исследование высоконапор-ных ступеней с осерадиальными колесами для стационарных компрессоров общего назначения / Диссертация на соискание степени кандидата технических наук. Ленинградский политех-нический институт. Ленингпад. - 1976. - 252 с.

7. Kalinkevych M, Obukhov O., et al. The design of vaned diffusers of centrifugal compressors based on the given velocity distribution. /7th International Conference on Compressors and their Systems. City University London, UK. - 2011. pp. 61 - 69. ISBN 978-0-85709-535-0 (ebook).

Отримана в редакції 02.06.2018, прийнята до друку 03.07.2018 